\title{
Performance Analysis of Immune Plasma Algorithm with Different Donor-Receiver Configurations
}

\author{
Sadat Duraki ${ }^{1}$, Selçuk Aslan ${ }^{2}$, Sercan Demirci $^{3 *}$ \\ ${ }^{1}$ Ondokuz Mayıs University, Faculty of Engineering, Department of Computer Engineering, Samsun, Turkey (ORCID: 0000-0001-8799-4455), \\ sadat.duraki@bil.omu.edu.tr \\ ${ }^{2}$ Erciyes University, Faculty of Aeronautics and Astronautics, Department of Aeronautical Engineering, Kayseri, Turkey (ORCID: 0000-0002-9145-239X), \\ selcukaslan@erciyes.edu.tr \\ 3* Ondokuz Mayıs University, Faculty of Engineering, Department of Computer Engineering, Samsun, Turkey (ORCID: 0000-0001-6739-7653), \\ sercan.demirci@bil.omu.edu.tr
}

(International Symposium on Multidisciplinary Studies and Innovative Technologies (ISMSIT) 2021 - 21-23 October 2021)

(DOI: 10.31590/ejosat.1024751)

ATIF/REFERENCE: Duraki, S., Aslan, S. \& Demirci, S. (2021). Performance Analysis of Immune Plasma Algorithm with Different Donor-Receiver Configurations. European Journal of Science and Technology, (29), 259-263.

\begin{abstract}
Immune Plasma Algorithm (IPA) is a novel meta-heuristic algorithm inspired by immune plasma transfer treatment. Many metaheuristic algorithms are used for solving complex optimization problems, but their performance is mostly inspected on problems with 30 dimensions. Nowadays we are dealing with far more complex systems that require solving high-dimensional optimization problems with over 50 dimensions whereas performance of meta-heuristic algorithms for high-dimensional problems is mostly unexamined. So to overcome this problem, in this study, performance of IPA on solving high-dimensional problems is investigated. In this case, it is used to solve five well-known benchmark optimization problems with 100 dimensions. In this work, Immune Plasma Algorithm (IPA) is used for solving Sphere, Quartic, Rastrigin, Ackley and Griewank functions. It is compared with some other stateof-the-art meta-heuristic algorithms. Experimental results demonstrate that IPA outperforms these algorithms in finding best objective values, and has best standard deviation, and best mean value for most of the tested optimization problems.
\end{abstract}

Keywords: High-dimensional Problems, Optimization, Immune Plasma Algorithm.

\section{Farklı Donör-Alıcı Konfigürasyonları ile İmmün Plazma Algoritmasının Performans Analizi}

\begin{abstract}
Öz
İmmün Plazma Algoritması (IPA), immün plazma transfer tedavisinden ilham alan yeni bir meta-sezgisel algoritmadır. Karmaşık optimizasyon problemlerini çözmek için birçok meta-sezgisel algoritma kullanılır, ancak performansları çoğunlukla 30 boyutlu problemlerde denetlenmiştir. Günümüzde 50 'den fazla boyutlu yüksek boyutlu optimizasyon problemlerinin çözülmesini gerektiren çok daha karmaşık sistemlerle uğraşıyoruz, ancak bu meta-sezgisel algoritmaların yüksek boyutlu problemler için performansı çoğunlukla incelenmemiştir. Bu problemin üstesinden gelmek için bu çalışmada IPA'nın yüksek boyutlu problemlerin çözümündeki performansı araştırılmıştır. Bu durumda, 100 boyutlu beş iyi bilinen kıyaslama optimizasyon problemini (Sphere, Quartic, Rastrigin, Ackley ve Griewank fonksiyonları) çözmek için IPA kullanılmıştır. Devamında, bazı son teknoloji meta-sezgisel algoritmalarla karşılaştırılmıştır. Deneysel sonuçlar, IPA'nın en iyi amaç değerlerini bulmada, bu algoritmalardan daha iyi performans gösterdiğini ve test edilen optimizasyon problemlerinin çoğu için en iyi standart sapmaya ve en iyi ortalama değere sahip olduğunu göstermektedir.
\end{abstract}

Anahtar Kelimeler: Yüksek boyutlu Problemler, Optimizasyon, İmmün Plazma Algoritması.

\footnotetext{
* Corresponding Author: sercan.demirci@bil.omu.edu.tr
} 


\section{Introduction}

In everyday life we are often encountered with problems that require finding their optimal solutions. There are two main approaches for finding optimal solutions, mathematical and heuristic approach. Although mathematical approaches such as calculating derivatives can lead to finding optimal solution, they are usually very complex to calculate especially when dealing with high dimensional problems. In recent years scientific and technological developments made possible making more powerful, effective and efficient systems, but this also caused even more complex systems in terms of number of variables and their structure. In the past, problems with 10-30 variables were considered as high dimensional problems, while nowadays problems with over 50 variables are evaluated as high dimensional problems.

There are multitude of works done on solving high dimensional problems using meta-heuristic algorithms, using Particle Swarm Optimization (PSO) [1], Artificial Bee Colony (ABC) [2], Animal Migration Optimization (AMO) [3], Salp Swarm Algorithm (SSA) [4], Firefly Algorithm [4], Grey Wolf Optimization [4], Moth-flame Optimizer (MFO) [4], Sine Cosine Algorithm (SCA) [4] and many others. It is worth mentioning that different algorithms perform differently depending on the given problems. This statement is also supported by No-FreeLunch (NFL) $[5,6]$ theorem, which claims that there is no single algorithm that obtains best results on all optimization problems. Likewise, performance of some algorithms tends to decrease significantly as number of variables increase. Thus, as a result of this theorem it can be said that designing new meta-heuristic algorithm and inspecting their performance on multidimensional and high-dimensional problems is vital for researches in the field of optimization.

In this study we investigated novel meta-heuristic algorithm named Immune Plasma Algorithm (IPA) [7] and its performance on solving high-dimensional problems. The rest of this study is organized as follows: In II Section is given explanation of Immune Plasma algorithm. In III Section experimental results of IPA and comparison with other heuristic algorithms are given. And finally, in IV Section conclusion and future work are given.

\section{Immune Plasma Algorithm}

Current global health crisis caused by COVID-19 lead to many researches, primarily done by medical experts in order to find best treatment. One of the approaches for treating patients infected by COVID-19 is by using immune plasma or convalescent plasma. When a virus, bacteria or any other foreign invader, enters our body, our immune system is responding by producing antibodies against it, which will destroy invader's cells [8]. After infection process, the immune response of each individual can be different. While some individuals have better immune response and get totally recovered from illness without getting any medical attention, others may not be fully recovered or may be in critical condition that requires some medical treatment. It all depends on how strong or weak one's immune system is. People who have a weak immune system, which cannot produce antibodies against the virus fast enough, may be treated with immune plasma that is directly transferred from recovered patients who have already been infected and have enough antibodies [9]. Author of [7] inspired by this treatment have designed novel meta-heuristic algorithm for solving optimization problems called Immune Plasma Algorithm (IPA). In IPA, every person in the population is considered as a possible solution for objective function that is being optimized. While immune response of the person represent quality of the solution. IPA has three main parts: Generating initial individuals, Infection spreading and immune system response, and Plasma extraction and transfer.

\subsection{Generating Initial Individuals}

Initial population is calculated by using (1). In (1) $x_{k j}$ represents $k t h$ person's $j t h$ decision parameter, there are D number of decision parameters for each person and total population size is PS. $x_{j}^{\text {low }}$ is lower and $x_{j}^{\text {high }}$ is upper bound of the $j$ th parameter. Whereas, $\operatorname{rand}(0,1)$ is randomly generated number between 0 and 1 .

$$
\begin{aligned}
& x_{k j}=x_{j}^{\text {low }}+\operatorname{rand}(0,1)\left(x_{j}^{\text {high }}-x_{j}^{\text {low }}\right) \\
& k=\{1,2, \ldots, P S\} \text { and } j=\{1,2, \ldots, D\}
\end{aligned}
$$

\subsection{Infection Spreading and Immune System Response}

In this part each individual is infected using (2). If the immune response (value of objective function) of the infected individual is better than the immune response before infection, then algorithm is storing newly generated immune system of the individual on the place of the old one, otherwise it keeps old immune system.

$$
\begin{aligned}
& x_{k j}^{i n f}=x_{k j}+\operatorname{rand}(-1,+1)\left(x_{k j}-x_{m j}\right) \\
& k=\{1,2, \ldots, P S\} \text { and } j=\{1,2, \ldots, D\}-\{k\}
\end{aligned}
$$

In (2) kth person's jth parameter is getting infected, represented with $\mathrm{x}_{k j}^{i n f}$. Likewise $\mathrm{x}_{k j}$ is $k$ th person's randomly selected $j$ th parameter. $x m j$ represents $j$ th parameter of randomly selected and previously infected person. And finally, rand $(-1$, +1 ) is randomly generated number between -1 and +1 .

\subsection{Plasma Extraction and Transfer}

After infection, immune responses of each individual is different, and depending on their immune response, IPA selects $\mathrm{NoD}$ (number of donors) individuals with best immune response as plasma donors and NoR (number of receivers) individuals with worst immune response as plasma receivers. After selecting donor and receivers plasma transfer is performed using (3). In (3), $x_{k j}^{r c v}$ is $k t h$ receiver's $j t h$ parameter. While $x_{m j}^{d n r}$ is randomly selected $m t h$ donor's $j t h$ parameter. Finally as a results of this process $x_{k j}^{r c v-p}$ is generated. It represents $k t h$ receiver's jth parameter after plasma transfer. 


$$
\begin{aligned}
& x_{k j}^{r c v-p}=x_{k j}^{r c v}+\operatorname{rand}(-1,+1)\left(x_{k j}^{r c v}-x_{m j}^{d r r}\right) \\
& j=\{1,2, \ldots, D\}
\end{aligned}
$$

After plasma treatment, IPA performs donor update. Purpose of this process is to change already used donors. Donor update process uses two different equations, and which equation will be used in generating new donor is determined in following manner. If the current evaluation divided by max evaluation is larger than randomly generated number between 0 and 1 , then (4) is used, otherwise (1) is used for generating new donor.

$$
x_{m j}^{d n r}=x_{m j}^{d n r}+\operatorname{rand}(-1,+1)\left(x_{m j}^{d n r}\right)
$$

High level overview of the IPA is shown on Fig. 1. For more detailed explanation and pseudo code of the algorithm [7] should be analyzed.

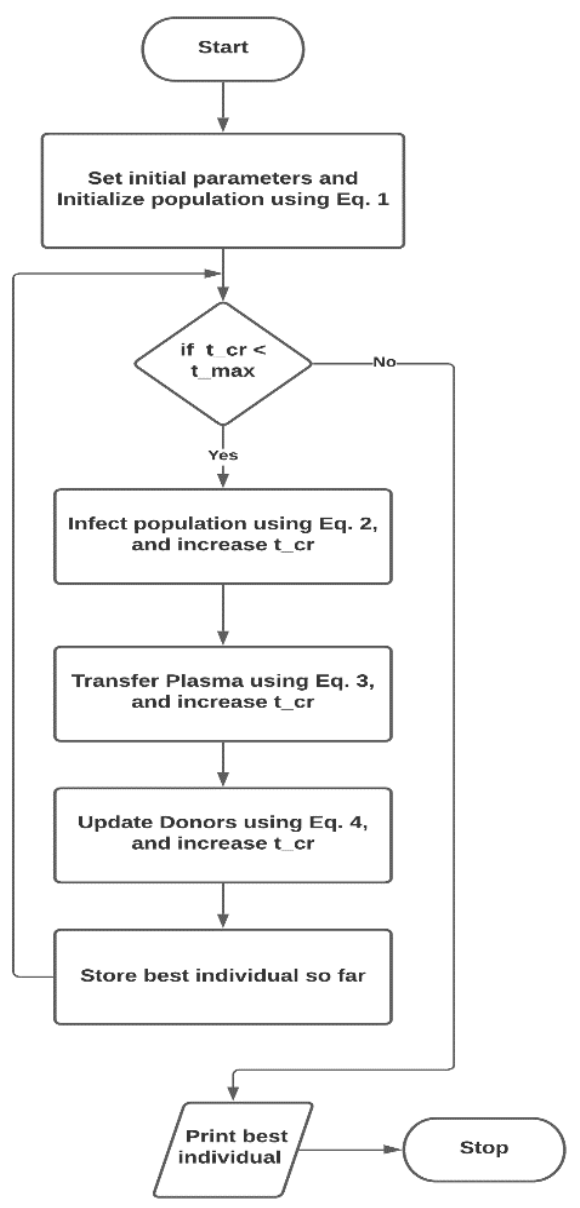

Figure 1. High level flowchart of IPA.

\section{Experimental Results}

In order to test performance of IPA for solving highdimensional optimization problems, 5 well-known benchmark optimization functions are taken. Names of the functions as well as formulation, range and global minimum value of the functions is given in Table I and their visuualization is shown on Fig. 2.

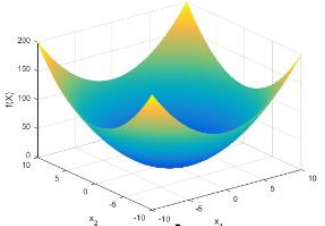

a)

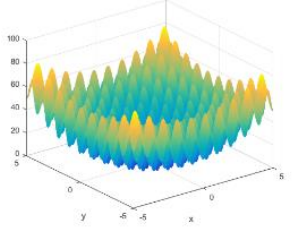

c)

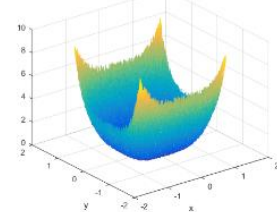

b)

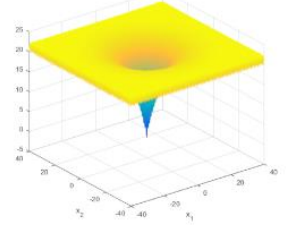

d)

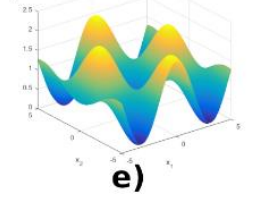

Figure 2. Visualization of Functions: (a) Sphere, (b) Quartic, (c) Rastrigin, (d) Ackley, (e) Griewank

After plasma treatment, IPA performs donor update. Purpose of this process is to change already used donors. Donor update process uses two different equations, and which equation will be used in generating new donor is determined in following manner. If the current evaluation divided by max evaluation is larger than randomly generated number between 0 and 1 , then (4) is used, otherwise (1) is used for generating new donor.

IPA can be run with different initial values, such as number of donor ( $\mathrm{NoD})$, number of receivers (NoR), population size (PS), maximum fitness evaluation (tmax), and number of parameters/dimensions (D). In order to obtain comparable results with other state-of-the-art algorithm [4], population size is set to 30 , maximum fitness evaluation is set to 15000 , and number of parameter (dimensions) for each optimization problem is set to 100 . These values are constant and they are not changed during this experiment. On the other hand, values of NoD and NoR have 7 different combinations. In first case values of NoD and NoR are equal to 1 , in second to 2 , in third to 3, in fourth to 4 , in fifth to 5 , in sixth to 6 and finally in seventh to 7 , and for each of these cases, 30 independent runs are performed. Thus for single optimization problem, 7 (cases) multiplied by 30 (independent runs), in total 150 independent runs are performed for every single optimization problems. Results of each run is recorded and the results are shown on 3. In this table are recorded mean value and standard deviation of 30 independent runs as well as overall best value of 30 independent runs. Likewise, best obtained results are bold in the Table 2 . 
Avrupa Bilim ve Teknoloji Dergisi

Table 1. Tested Functions With Range And Fmin

\begin{tabular}{|c|c|c|c|}
\hline Name & Function & Range & Fmin \\
\hline F1 (Sphere) & $f_{1}(x)=\sum_{i=1}^{n} x_{i}^{2}$ & {$[-100,100]$} & 0 \\
\hline F2 (Quartic) & $f_{2}(x)=\sum_{i=1}^{n} i x_{i}^{4}+\operatorname{random}[0,1)$ & {$[-1.28,1.28]$} & 0 \\
\hline F3 (Rastrigin) & $f_{3}(x)=\sum_{i=1}^{n}\left(x_{i}^{2}-10 \cos \left(2 \pi x_{i}\right)+10\right)$ & {$[-5.12,5.12]$} & 0 \\
\hline F4 (Ackley) & $f_{4}(x)=-20 \exp \left(-0.2 \sqrt{\frac{1}{D} \sum_{i=1}^{n} x_{i}^{2}}\right)-\exp \left(\frac{1}{D} \sum_{i=1}^{D} \cos \left(2 \pi x_{i}\right)\right)+20+e$ & {$[-32,32]$} & 0 \\
\hline F5 (Griewank) & $f_{5}(x)=\frac{1}{4000} \sum_{i=1}^{D} x_{i}^{2}-\prod_{i=1}^{D} \cos \left(\frac{x_{i}}{\sqrt{i}}\right)+1$ & {$[-600,600]$} & 0 \\
\hline
\end{tabular}

Table 2. Results Of The Ipa With Different Nor And Nod Parameter Values For 100 Dimension Problems.

\begin{tabular}{|c|c|c|c|c|c|c|c|c|}
\hline Function & & $\mathrm{NoR}=\mathrm{NoD}=1$ & $\mathrm{NoR}=\mathrm{NoD}=2$ & $\mathrm{NoR}=\mathrm{NoD}=3$ & $\mathrm{NoR}=\mathrm{NoD}=4$ & $\mathrm{NoR}=\mathrm{NoD}=5$ & $\mathrm{NoR}=\mathrm{NoD}=6$ & $\mathrm{NoR}=\mathrm{NoD}=7$ \\
\hline F1 (Sphere) & Mean & $1.68 \mathrm{e}-09$ & $2.20 \mathrm{e}-14$ & $4.08 \mathrm{e}-16$ & $2.05 e-16$ & 5.24e-19 & $5.73 \mathrm{e}-18$ & $6.16 \mathrm{e}-18$ \\
\hline & Std. & $2.01 \mathrm{e}-09$ & $4.35 \mathrm{e}-14$ & $1.32 \mathrm{e}-15$ & $7.55 e-16$ & $1.46 \mathrm{e}-18$ & $1.60 \mathrm{e}-17$ & $1.40 \mathrm{e}-17$ \\
\hline & Best & $5.07 \mathrm{e}-15$ & $9.90 \mathrm{e}-22$ & $1.16 \mathrm{e}-26$ & $3.60 \mathrm{e}-29$ & $2.96 \mathrm{e}-25$ & $1.18 \mathrm{e}-25$ & $1.98 \mathrm{e}-24$ \\
\hline$\overline{\text { F2 (Quartic) }}$ & Mean & 0.07 & 0.01 & 0.008 & 0.006 & 0.004 & 0.006 & 0.007 \\
\hline & Std. & 0.16 & 0.01 & 0.005 & 0.006 & 0.005 & 0.006 & 0.004 \\
\hline & Best & 0.0006 & 0.002 & 0.001 & 0.0003 & 0.0005 & 0.001 & 0.0005 \\
\hline F3 (Rastrigin) & Mean & 42.95 & 89.76 & 25.32 & $5.93 \mathrm{e}-08$ & 0.0 & 0.0 & 0.0 \\
\hline & Std. & 158.79 & 232.74 & 138.70 & $2.25 \mathrm{e}-07$ & 0.0 & 0.0 & 0.0 \\
\hline & Best & 0.0 & 0.0 & 0.0 & 0.0 & 0.0 & 0.0 & 0.0 \\
\hline F4 (Ackley) & Mean & 0.03 & 8.01 & 13.36 & 16.73 & 17.43 & 18.80 & 18.83 \\
\hline & Std. & 0.17 & 9.98 & 9.60 & 7.61 & 6.95 & 5.11 & 5.12 \\
\hline & Best & $1.07 \mathrm{e}-09$ & $8.56 \mathrm{e}-11$ & $1.06 \mathrm{e}-08$ & $1.15 \mathrm{e}-10$ & $2.65 \mathrm{e}-11$ & $8.17 \mathrm{e}-11$ & $9.72 \mathrm{e}-11$ \\
\hline$\overline{\text { F5 (Griewank) }}$ & Mean & $1.16 \mathrm{e}-08$ & $7.52 \mathrm{e}-09$ & $6.80 \mathrm{e}-14$ & $3.20 \mathrm{e}-13$ & $1.48 \mathrm{e}-17$ & $8.88 \mathrm{e}-17$ & $2.55 \mathrm{e}-16$ \\
\hline & Std. & $4.58 \mathrm{e}-08$ & $2.86 \mathrm{e}-08$ & $1.68 \mathrm{e}-13$ & $1.21 \mathrm{e}-12$ & 8.10e-17 & $3.38 \mathrm{e}-16$ & $8.76 \mathrm{e}-16$ \\
\hline & Best & $1.33 \mathrm{e}-15$ & 0.0 & 0.0 & 0.0 & 0.0 & 0.0 & 0.0 \\
\hline
\end{tabular}




\section{Conclusion and Future Work}

In this study performance of IPA solving high-dimensional problems is investigated. Using IPA five well-known optimization problems are solved. Results obtain by the IPA are compared with five other state-of-the-art meta-heuristic algorithms. From the Table 3 can be concluded that finding optimal number of donors and receivers is important. Experimental results showed that optimal number for donors and receivers is between 4 and 6 . By looking at the comparison table it can be concluded that IPA outperforms all five algorithm in finding overall best objective function value. Likewise, it has better standard deviation and mean values, except for the Ackley function, where GWO algorithm had better mean and standard deviation values, and IPA had second best values.

In future, IPA's performance can be investigated on solving different optimization problems, in even higher demsions, and compared with some other state-of-the-art algorithms.

\section{References}

Jia, D., Zheng, G., Qu, B., and Khan, M. K., "A hybrid particle swarm optimization algorithm for high-dimensional problems." Computers and Industrial Engineering, 61(4), pp. 1117-1122, 2011.

Li, Z., Wang, W., Yan, Y., and Li, Z., "PS-ABC: A hybrid algorithm based on particle swarm and artificial bee colony for high-dimensional optimization problems." Expert Systems with Applications, 42(22), pp. 8881-8895. 2015

Lai, Z., Feng, X., and Yu, H. “An Improved Animal Migration Optimization Algorithm Based on Interactive Learning Behavior for High Dimensional Optimization Problem.” In 2019 International Conference on High Performance Big Data and Intelligent Systems (HPBD\&IS), pp. 110-115, May 2019, IEEE.

Nautiyal, B., Prakash, R., Vimal, V., Liang, G., and Chen, H. "Improved Salp Swarm Algorithm with mutation schemes for solving global optimization and engineering problems." Engineering with Computers, pp. 1-23. 2021.

I. Boussaid, J. Lepagnot, P. Siarry, "A survey on optimization metaheuristics”, Inf. Sci., vol. 237, pp. 82-117, 2013.

X.-S. Yang, "Nature-inspired optimization algorithms: Challenges and open problems", J. Comput. Sci., vol. 46, 2020.

Aslan, S., and Demirci, S., "Immune Plasma Algorithm: A Novel Meta-Heuristic for Optimization Problems." IEEE Access, 8, pp.220227-220245, 2020.

U.S. Department of Health and Human Services, "Understanding the immune system how it works", Nat. Inst. Allergy Infectious Diseases, Washington, DC, USA, Tech. Rep. 07-5423:1-63, 2007.

C. Shen, Z. Wang, F. Zhao, Y. Yang, J. Li, J. Yuan, F. Wang, D. Li, M. Yang, L. Xing, "Treatment of 5 critically ill patients with COVID-19 with convalescent plasma", Jama, vol. 323, no. 16, pp. 1582-589, 2020.

Mirjalili, S., Gandomi, A. H., Mirjalili, S. Z., Saremi, S., Faris, H., and Mirjalili, S. M. "Salp Swarm Algorithm: A bio- inspired optimizer for engineering design problems". Advances in Engineering Software, 114, pp. 163-191. 2017.

Yang, X. S. "Firefly algorithm, Levy flights and global optimization." In Research and development in intelligent systems XXVI, pp. 209-218. 2010. Springer, London.

Mirjalili, S., Mirjalili, S. M., and Lewis, A. "Grey wolf optimizer." Advances in engineering software, 69, pp. 4661. (2014).

Mirjalili, S. "Moth-flame optimization algorithm: A novel nature-inspired heuristic paradigm." Knowledge-based systems, 89, pp. 228-249. (2015).

Mirjalili, S. (2016). SCA: a sine cosine algorithm for solving optimization problems. Knowledge-based systems, 96, pp. 120-133. 